\title{
Scope of Air Quality Monitoring Within the Network of Public Health Institutes in Republic of Serbia
}

\author{
BRANISLAVA I. MATIĆ, Institute of Public Health of Serbia \\ „Dr Milan Jovanović Batut“, Belgrade \\ SNEŽANA M. DEJANOVIĆ, Institute of Public Health of Serbia \\ „Dr Milan Jovanović Batut“, Belgrade
}

\author{
Original scientific paper \\ UDC: 502.3:502.175(497.11) \\ 614.2(497.11) \\ DOI: 10.5937/tehnika2002261M
}

\begin{abstract}
Coal burning power plants, household solid fuel combustion, industrial contamination, traffic, and topography of urban settings are key reasons for labelling air pollution as a serious public health threat for urban population in Republic of Serbia, where air quality $(A Q)$ is monitored by both National and Local network of measuring stations. The research tool in this cross-sectional study is a database formed by the Institute of Public Health of Serbia (IPHS) as a part of continuous AQ monitoring process for the Ministry of Health, through regular reporting of local IPHs, from the Network of Public Health Institutes (Network). Depending on the Local AQ monitoring Program, sources of continuous air pollution and pollutants' chemical nature, local IPHs monitor among the following: $\mathrm{SO}_{2}$, black carbon (BC), $\mathrm{NO}_{2}$, total atmospheric deposited matter, BeToXy, $P M_{10}$ and $\mathrm{PM}_{2.5}$. $\mathrm{SO}_{2}$ and $\mathrm{BC}$ are measured daily. In 2018, 18 out of 25 Network IPHs monitored $A Q$ for any of the given parameters: $\mathrm{SO}_{2}$ at 76 measuring points in 33 urban settlements; both $\mathrm{BC}$ and $\mathrm{NO}_{2}$ at 70 measuring points in 31 settlements. The pollutants most needed to be monitored are $P M_{10}$ and $P M_{2.5}$ particles, but are still monitored with the least frequency within the Network. Only 8 out of 25 IPHs monitors PM 10 in 15 settlements at 28 measuring points. Local programs of $A Q$ monitoring in Serbia, conducted with the participation of the IPHs Network, give an incomplete coverage of potential public health threats for quantifying the burden of disease originating from urban air pollution.
\end{abstract}

Key words: air quality, Public Health Network, Serbia

\section{INTRODUCTION}

Air pollution, from both outdoor and indoor sources, represents the single largest environmental risk to health globally. WHO estimated that air pollution was responsible for more than 550000 premature deaths in the WHO European Region in 2016, almost 6.600 of which were attributed to air pollution in Serbia. This disease burden is preventable, if air quality improves [1]. Coal burning power plants, household solid fuel combustion, industrial contamination, traffic, and topographic position of urban settings are key reason for labeling air pollution as a serious public health threat for urban population in Republic of Serbia [2].

Author's address: Branislava Matić, Institute of Public Health of Serbia, „Dr Milan Jovanović Batut“, Belgrade, Dr Subotića starijeg 5

e-mail: brankicam@batut.org.rs

Paper received: 13.03.2020.

Paper accepted: 26.03.2020.
AQ is monitored by both National and Local network of measuring stations. National network of automatic measuring stations (AMSs) consists of 40 stations, being distributed and maintained by the Serbian Environment Protection Agency (SEPA) [3].

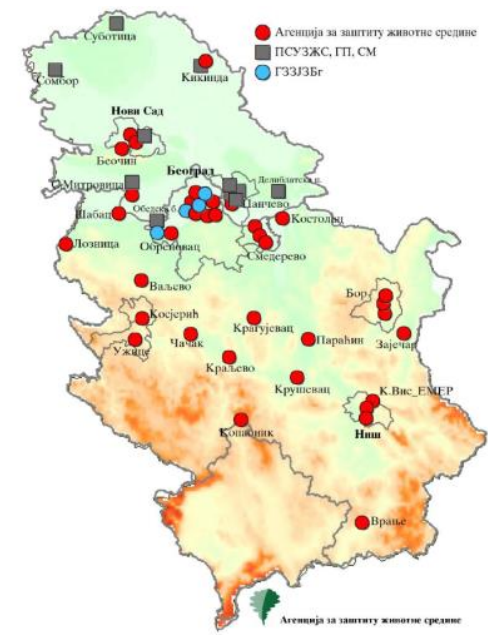

Figure 1 - SEPA network of AMSS 
Besides the broad terrestrial distribution of SEPA's AMSs (Figure 1), their number is still accounted as insufficient. In order to increase the density of AQ monitoring, local self-government administration is contracting with other stakeholders able to carry out this task, which, in most of the cases is a local IPH, belonging jointly to the Network of IPHs, a constitutive part of the health sector of the Republic of Serbia $[4,5,6]$. Official administrator for the Local Network is local self-government [7]. In total, 25 institutions comprise the Network of Public Health Institutes (PHIs) in Serbia (Figure 2), lead by the National PHI $(1+24)$, of which AQ laboratories are operational in 20 of them [6].

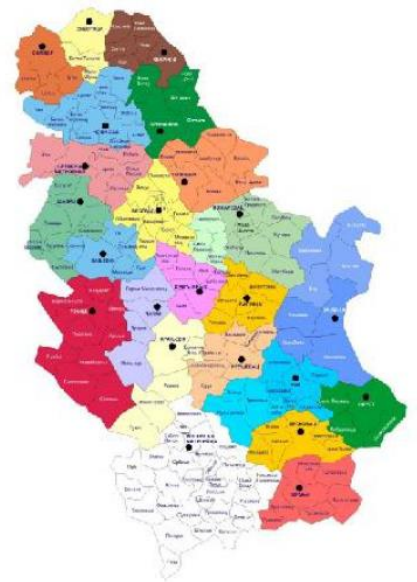

Figure 2 - IPHs Network

Our aim was to present the scope of urban AQ quality monitoring undertaken by the above-mentioned laboratories, as part of a mix of stations belonging to both the State Network of AMS and the network of local measuring stations. Also, we aimed to present a decreasing trend in monitoring, in general, when these legal entities are the case.

\section{METHODS AND DATA COLLECTION}

The research tool used in this cross-sectional study is a data base formed by the Institute of Public Health of Serbia (IPHS), as a segment of a continuous AQ monitoring process implemented for the Ministry of Health, through regular reporting of local IPHs from the Network. Sampling, measuring and analyzing level of defined indicators are done by environmental health departments of local/regional IPHs. Data collation, processing and analysis are undertaken by the IPHS, whose assignment is to forward its remarks on possible public health risks to decision-makers. Due to the clear market conditions established in the field of operation of accredited laboratories, the data collected at the IPHS may vary from year to year [4].

Indicators that are monitored are grouped according to the nature of pollution sources, population coverage, traffic density and potential public health risks: $\mathrm{SO}_{2}$, black carbon (BC), $\mathrm{NO}_{2}$ and other specific pollutants, such as $\mathrm{NH}_{3}, \mathrm{PM}_{10}$, heavy metals, and traffic-originated organic chemicals. Together with the key stakeholders at the local level (local self-government, local IPH), each municipality/town produces a Local Action Plan for AQ monitoring, defining the time schedule of monitoring activities and spatial distribution of sampling points, sources of air pollution and choice of pollutants in need of monitoring. Sulfur dioxide and $\mathrm{BC}$ are measured daily due to the strong correlation among their ambient air concentrations and fossil fuel combustion, as Serbia's key energy source is lignite coal [8]. $\mathrm{NO}_{2}$ is the most frequently measured specific pollutant, on daily basis.

Presence of particulate pollution in ambient air is monitored through sampling of coarse particles of total atmospheric deposition ( $\left.\mathrm{mg} / \mathrm{m}^{2} / \mathrm{day}\right), \mathrm{PM}_{10}$ and $\mathrm{PM}_{2.5}$, with different measurement frequency, according to local AQ monitoring plans and specific indication, depending on pollution sources and financial resources of the local administration and the polluter, per se [9].

\section{RESULTS}

$\mathrm{SO}_{2}$ and $\mathrm{BC}$ are measured on daily basis. In 2018 , 18 out of 25 IPHs from the Network has monitored AQ for any of the given parameters, with the following distribution: $\mathrm{SO}_{2}$ measurements covered 76 measuring points in 33 urban settlements; $\mathrm{BC} 70$ measuring points in 31 urban settlements; as traffic-induced pollutant $\mathrm{NO}_{2}$, measured also in 31 urban environments at 70 measuring points. Table 1 presents the overall picture of monitoring dynamics for the period 2009 - 2018, performed for $\mathrm{SO}_{2}$, BS and specific pollutants (SPs) by the local IPHs. (Table 1).

Table 1. AQ monitoring dynamics by the IPH Network

\begin{tabular}{|l|l|l|l|l|l|l|}
\hline \multirow{2}{*}{ Year } & \multicolumn{2}{|l|}{ Towns } & \multicolumn{3}{l|}{ Samplng sites } \\
\cline { 2 - 7 } & $\mathrm{SO}_{2}$ & $\mathrm{BC}$ & $\mathrm{SPs}$ & $\mathrm{SO}_{2}$ & $\mathrm{BC}$ & $\mathrm{SPs}$ \\
\hline 2009. & 32 & 32 & 23 & 91 & 91 & 62 \\
\hline 2010. & 32 & 32 & 29 & 95 & 95 & 78 \\
\hline 2011. & 31 & 31 & 27 & 75 & 75 & 63 \\
\hline 2012. & 34 & 34 & 34 & 93 & 93 & 85 \\
\hline 2013. & 32 & 32 & 33 & 83 & 83 & 81 \\
\hline 2014. & 27 & 27 & 26 & 60 & 60 & 45 \\
\hline 2015. & 32 & 32 & 29 & 61 & 62 & 61 \\
\hline 2016. & 27 & 26 & 27 & 52 & 56 & 47 \\
\hline 2017. & 32 & 30 & 29 & 62 & 59 & 60 \\
\hline 2018. & 33 & 31 & 31 & 76 & 70 & 71 \\
\hline
\end{tabular}

If we analyze the data trend line, we clearly note that a decrease in the dynamics occurred steadily, throughout the last decade, for both general pollutants $\left(\mathrm{SO}_{2}, \mathrm{BC}\right)$, and the heterogeneous group of ,specific 
pollutants", strictly speaking of the IPHs Network activities (Figure 3 - 4).

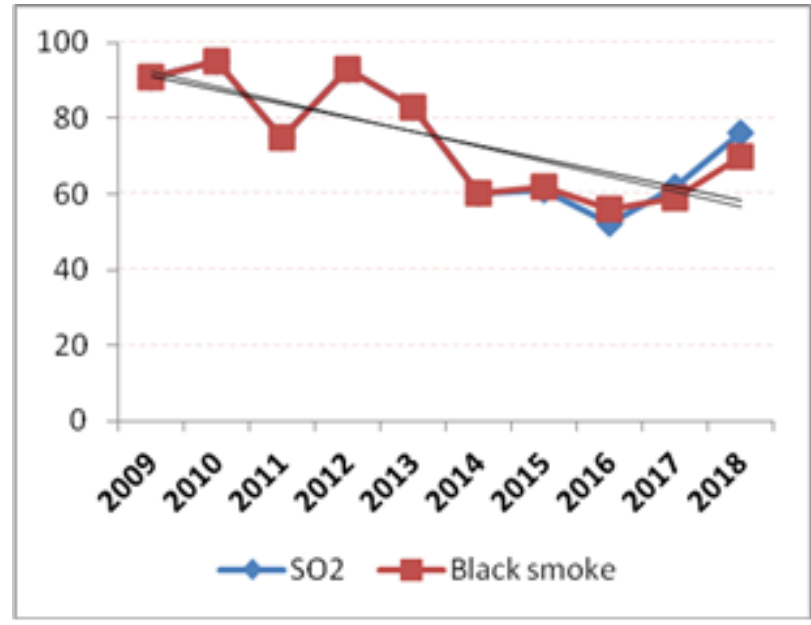

Figure 3 - Trend line of $\mathrm{SO}_{2}, \mathrm{BC}$ measuring dynamics

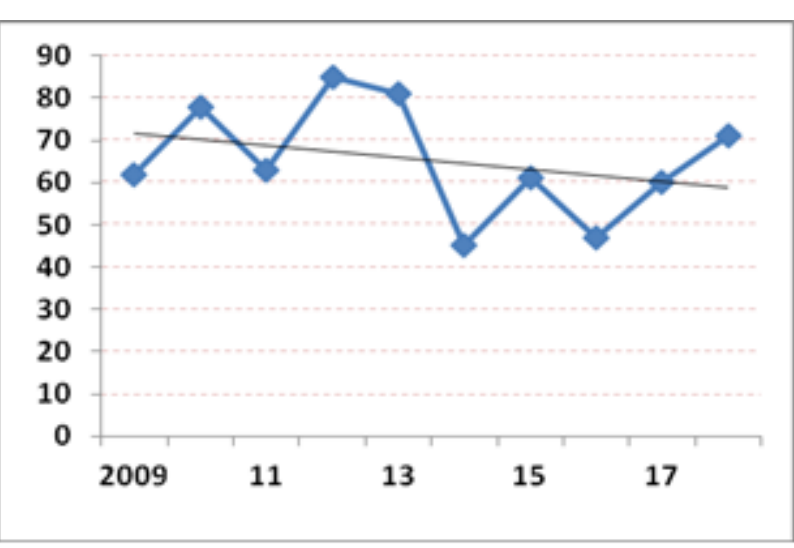

Figure 4 - Trend line of SPs measuring dynamics

Further on, in analyzing the frequency of $\mathrm{NO}_{2}$ measuring, together with other specific indicators of urban ambient air pollution in 2018, the distribution of frequencies for 31 urban settings is as follows: pollutants are sampled at 1 sampling site in 18 urban settings/towns; at 2 sites in 6 towns; at 3 sites in 2 towns; at 4 sites in 3 towns; at 6 sites in 1 town, and at 17 sites in only 1 urban setting (capital city of Belgrade).

Among all of the SPs, the pollutants most needed to be monitored are $\mathrm{PM}_{10}$ and $\mathrm{PM}_{2.5}$ particles, but are still monitored with the least frequency within the Network of IPHs. Only 8 out of 25 IPHs monitors $\mathrm{PM}_{10}$, in 15 urban settlements at 20 measuring points (Table 2). The other public health mischief is that among them, only in 5 settlements (Veliki Crljeni, Obrenovac, Kraljevo, Sremska Mitrovica, Užice), the parameter is measured continuously, while in other 10 it is performed only once in a week, which is insufficient for any serious EHIA analysis. Regular air sampling for the $\mathrm{PM}_{10}$ contents is of essential importance, as those two municipalities are hosting two lignit-burning power plants, of which, the one in Obrenovac is the largest in the Western Balkans Region, marking it as a source of substantial public health concern [12].

Table 2. Scope of $P M_{10}$ monitoring in 2018

\begin{tabular}{|l|c|c|c|c|}
\hline Town & $\begin{array}{l}\text { samplin } \\
\text { g sites }\end{array}$ & $\begin{array}{l}\text { sampling } \\
\text { episodes }\end{array}$ & $\begin{array}{l}\text { Above } \\
\text { ALV }\end{array}$ & \% \\
\hline Bor & 3 & 315 & 141 & 44.76 \\
\hline V. Crljeni & 1 & 365 & 126 & 34.52 \\
\hline Elemir & 1 & 35 & 0 & 0 \\
\hline Zrenjanin & 2 & 147 & 5 & 3.40 \\
\hline Ivanjica & 1 & 55 & 15 & 27.27 \\
\hline Kraljevo & 1 & 356 & 105 & 29.49 \\
\hline Lazarevac & 1 & 365 & 67 & 18.36 \\
\hline Niš & 1 & 47 & 16 & 34.0 \\
\hline Obrenovac & 1 & 365 & 46 & 12.6 \\
\hline Pančevo & 2 & 380 & 176 & 46.3 \\
\hline & & & & \\
\hline S.Mitrovica & 1 & 354 & 58 & 16.38 \\
\hline Ćuprija & 1 & 48 & 33 & 68.75 \\
\hline Užice & 1 & 328 & 95 & 29.14 \\
\hline Čačak & 1 & 56 & 25 & 44.64 \\
\hline Šabac & 2 & 204 & 0 & 0 \\
\hline & $\mathbf{2 0}$ & & & $\mathbf{2 7 . 3 1}$ \\
\hline
\end{tabular}

The same disproportion is met in the capital city of Belgrade (agglomeration), having only 2 sampling sites with continuous $\mathrm{PM}_{10}$ monitoring, while the other 7 are engaged only once in a week.

Table 3. Scope of $P M_{10}$ monitoring in Belgrade City (2018)

\begin{tabular}{|c|c|c|c|c|}
\hline Measuring points & & Days & $\begin{array}{l}\text { Above } \\
\text { ALV }\end{array}$ & $\%$ \\
\hline AMS Ovča & \multirow[t]{2}{*}{ daily } & 365 & 70 & 19,18 \\
\hline Zemun, J.Kopitara & & 365 & 118 & 32,33 \\
\hline KBC "Dr D.Mišović" & \multirow{7}{*}{ 1/week } & 52 & 14 & 26,92 \\
\hline BAS, Železnička 4 & & 52 & 14 & 26,92 \\
\hline Rakovica, O.Š. & & 52 & 6 & 11,54 \\
\hline Krnjača 1 & & 52 & 14 & 26,92 \\
\hline Krnjača 2 & & 52 & 12 & 23,08 \\
\hline B.Oslobođenja 18 & & 52 & 13 & 25,0 \\
\hline \multirow[t]{2}{*}{ Zemun } & & 52 & 15 & 28,85 \\
\hline & 9 & & & 24,53 \\
\hline
\end{tabular}

\section{DISCUSSION}

Besides pure technical AQ measuring practice, local IPHs pursue their expertise with the local administrative bodies established for the cause of environmental pollution prevention, which is, also, a legally-defined activity $[6,10]$. One of the most substantial improvements in local ambient AQ was implemented in the 
town of Užice (West Serbia), known for its historical high levels of $\mathrm{BC}$, generating from household fossil fuel combustion, in combination with its specific terrain topography. These long-lasting mix of environmental conditions was recognized by the expert community as a cause of different, mostly respiratory, health problems [11]. Due to locally adopted by-laws and financial subsidies for switching to other energy sources and pollution sustainable heating modes, Užice is experiencing a steep drop in the $\mathrm{BC}$ pollution trend line (Figure 5).

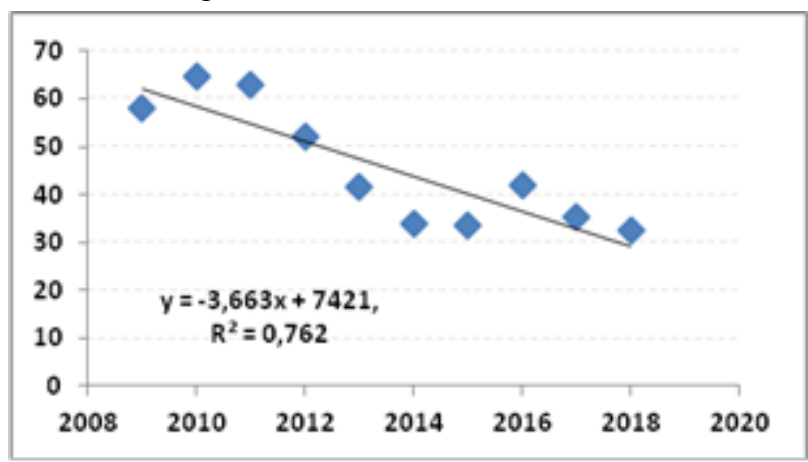

Figure 5 - Užice - decrease of BC annual mean values

The measures applied in Užice local self-government are in line with suggestions given by the European Environment Agency on the issue of local authorities as legal entities responsible for giving examples on air pollution mitigation measures [12]. As given in this EEA publication, local measures include expanding district heating, using cleaner fuels for heating, introducing lowemission transport zones, switching to cleaner buses or trams, promoting cycling, lowering speed limits and issuing congestion charges. Because of the variety of these measures and the different types of city, there is not one specific solution that fits all cities. What is remarkable about these measures is that they both reduce local air pollution and improve the quality of life in those cities. Furthermore, they cut greenhouse gas emissions and, in many cases, save money.

Last but not least, local IPHs are filling-in the data to the IPHS database for admissions to primary health care units on cases of exacerbation of asthma bronchiale and COPD (chronic obstructive pulmonary disease), which is, then, used to distribute them spatially using GIS in comparison to high mean annual concentration of $\mathrm{PM}_{10}$ and $\mathrm{BC}$ [13].

\section{CONCLUSIONS}

Local programs of AQ monitoring in Serbia, conducted by the Network of IPHs give an incomplete coverage of potential public health threats for quantifying the burden of disease originating from urban air pollution. One of the main reasons for such a situation is the constant non-compliance with the provisions of the legislation of those stakeholders (any accredited laboratory, be it private or public) who are obliged to forward all data on pollution monitoring in any environmental medium to the public health authority in charge of a specific territory, as well as to the IPHS, responsible for the country level [14].

\section{REFERENCES}

[1] Health impact of ambient air pollution in Serbia - A call to action;World Health Organization 2019. http://www.euro.who.int/_data/assets/pdf_file/002 0/412742/Health-impact-pollution-Serbia.pdf?ua=1

[2] Matić B, Rakić U, Janjić O, Tasić V, Scope of ambient air PM10 monitoring within the network of local public health institutions in Serbia, in Proc. The Sixth International WeBIOPATR Workshop \& Conference Particulate Matter: Research and Management WeBIOPATR 2017, Belgrade, pp. 144-147, ISBN: 978-86-7306-152-8, 6-8 September 2017.

[3] Regulation establishing The Program of Air Quality Control in the State Network Off. gazette RS, No.58/2011

[4] Rulebook on Conditions for Issuance of a Permit for Measuring Air Quality and a Permit for Measuring Emissions from Stationary Pollution Sources Off. gazette RS, No.1/2012

[5] Regulation on the plan of the network of healthcare institutions Off. gazette RS, No. 68/2019

[6] Law on Public Health Off. gazette RS, No. 15/2016

[7] Rulebook on the content of air quality plans Off. gazette RS, No. 21/2010

[8] Jovanović V. V, Komatina M, NOx and SO2 emission factors for Serbian Lignite Kolubara, THERMAL SCIENCE, Vol.16. No.4, pp. 1213-1228, 2016.

[9] Regulation on monitoring conditions and air quality requirements Off. gazette $R S$, No. 11/2010, 75/2010, $63 / 2013$

[10]Rulebook on closer conditions for implementing public health in the field of environmental health of the population Off. gazette RS, No. 34/2019

[11]Tomić-Špirić V, Kovačević G, Marinković J, Janković J et al, Evaluation of the Impact of Black Carbon on the Worsening of Allergic Respiratory Diseases in the Region of Western Serbia: A Time-Stratified Case Crossover Study. Medicina (Kaunas), 2019; 55 (6):261 http://dx.doi.org/10.3390/medicina55060261 
[12]European Environment Agency: Air Pollution - Local authorities lead by example with effective air pollution mitigation measures https://www.eea.europa.eu/downloads/3555b7a16e1d4d89826ff0e6ba1eb a9e/1576678270/local-authorities-lead-by-example.pdf, 2019.

[13]Institut za javno zdravlje Srbije „Dr Milan Jovanović Batut" Zdravstveni indikatori životne sredine u Re- publici Srbiji u 2015.godini (ENHIS): 52-53 http://www.batut.org.rs/download/izvestaji/higijena/Zdrav stveni\%20indikatori\%20zivotne\%20sredine\%20201 5.pdf, 2016.

[1] Law on Health Documentation and Records in the Field of Health, "Official Gazette of RS", No. $123 / 2014,106 / 2015$.

\section{REZIME}

\section{OBIM MONITORINGA KVALITETA VAZDUHA U MREŽI INSTITUCIJA JAVNOG ZDRAVLJA U REPUBLICI SRBIJI}

Termoelektrane na ugalj, sagorevanje čvrstog goriva u domaćinstvu, industrijska kontaminacija, saobraćaj i topografija urbanih sredina su ključni razlozi za markiranje zagađenja vazduha kao ozbiljne javno-zdravstvene pretnje izloženog gradskog stanovništva. Kvalitet vazduha (KV) prate kako nacionalna tako i lokalna mreža mernih stanica. Cilj ovog rada je da prikaže srazmere udela institucija javnog zdravlja u monitoring KV u Srbiji. Instrument istraživanja u ovoj studiji preseka je baza podataka formirana od strane Instituta za javno zdravlje Srbije (IJZS) kao komponenta kontinuiranog procesa praćenja KV za Ministarstva zdravlja, kroz redovno izveštavanje lokalnih ZJZ, iz Mreže zavoda za javno zdravlje (Mreža). U zavisnosti od lokalnog programa praćenja KV, izvora kontinuiranog zagađenja vazduha i hemijske prirode zagađivača, lokalni $\mathrm{ZJZ}$ prate sledeće parametre: $\mathrm{SO}_{2}$, čađ, $\mathrm{NO}_{2}$, ukupne taložne materije, BeToXy, PM 10 i PM 2.5. SO 2 čađ se mere dnevno. U 2018. godini 18 od 25 lokalnih ZJZ pratilo je $\mathrm{KV}$ za bilo koji od zadatih parametara: $\mathrm{SO}_{2}$ na 76 mernih mesta u 33 naselja; čađ $i \mathrm{NO} 2$ na 70 mernih mesta u 31-om naselju. Polutanti čiji je monitoring od prioriteta su čestice tipa PM $M_{10} i$ $P M_{2.5}$, a iste se prate sa najmanjom učestalošću unutar mreže. Samo 8 od 25 ZJZ prati PM 10 u 15 naselja na 28 mernih mesta. Lokalni programi monitoringa AK u Srbiji, sprovedeni uz učešce MZP-a, daju nepotpuno pokrivanje potencijalnih pretnji po javno zdravlje za kvantifikaciju tereta bolesti koje potiču od zagađenja urbanog vazduha.

Ključne reči: kvalitet vazduha, mreža javnog zdravlja, Srbija 